\title{
Pengaruh Faktor Instrinsik dan Ekstrinsik terhadap Pelaksanaan Inisiasi Menyusu Dini oleh Bidan di Puskesmas Rawat Inap
}

\section{The Influence of Intrinsic and Extrinsic Factors to Early Initiation of Breastfeeding Implementation by Midwives in Inpatient Health Center}

\author{
Rismaina Putri $i^{1}$, I Wayan Agung I', Sri Andarini ${ }^{3}$ \\ ${ }^{1}$ Program Magister Kebidanan Fakultas Kedokteran Universitas Brawijaya \\ ${ }^{2}$ Fakultas Kedokteran Universitas Brawijaya-RSUD Saiful Anwar Malang \\ ${ }^{3}$ Fakultas Kedokteran Universitas Brawijaya Malang
}

\begin{abstract}
ABSTRAK
Inisiasi Menyusu Dini (IMD) adalah proses alami dimana bayi mulai menyusu sendiri segera setelah lahir kontak kulit dengan kulit ibunya hingga 1 (satu) jam setelah lahir. Meskipun IMD wajib dilakukan bidan dalam proses persalinan namun belum semua bidan melaksanakannya dengan baik. Terdapat beberapa faktor intrinsik dan ekstrinsik yang mempengaruhi pelaksanaan IMD. Penelitian ini bertujuan mengetahui pengaruh faktor intrinsik yang meliputi karakteristik bidan (umur, pendidikan, masa kerja), pengetahuan, sikap dan motivasi dan faktor ekstrinsik bidan yang meliputi pelatihan, beban kerja dan imbalan terhadap pelaksanaan Inisiasi Menyusu Dini di Puskesmas Rawat Inap Kabupaten Pasuruan. Penelitian ini menggunakan desain penelitian observasional analitik secara case control dan dengan tehnik purposive sampling. Penelitian ini dilaksanakan di 3 (tiga) Puskesmas Rawat Inap Kabupaten Pasuruan yaitu Puskesmas Gondangwetan, Purwodadi dan Winongan pada bulan November - Desember 2013. Besar sampel dalam penelitian ini adalah 40 orang. Setiap subjek diobservasi dengan lembar observasi saat melaksanakan IMD kemudian mengisi kuisioner untuk mengukur faktor intrinsik yaitu karakteristik bidan (umur, pendidikan, masa kerja), pengetahuan, sikap dan motivasi dan faktor ekstrinsik bidan yaitu pelatihan, beban kerja dan imbalan. Analisis hasil penelitian menggunakan uji analisis jalur. Hasil penelitian menemukan bahwa faktor intrinsik dan faktor ekstrinsik bidan berpengaruh terhadap pelaksanaan IMD di Puskesmas Rawat Inap Kabupaten Pasuruan. Variabel yang berpengaruh langsung terhadap pelaksanaan IMD di Puskesmas Rawat Inap Kabupaten Pasuruan adalah sikap bidan (2,78\%), beban kerja yaitu jumlah persalinan/minggu $(0,26 \%)$ dan jumlah jam kerja bidan/minggu (1,54\%) serta motivasi $(0,44 \%)$. Umur $(14,51 \%)$, pendidikan (2\%), masa kerja $(7,67 \%)$, pengetahuan $(0,26 \%)$, pelatihan $(8 \%)$, dan imbalan $(0,06 \%)$ merupakan faktor yang berpengaruh tidak langsung terhadap pelaksanaan IMD di Puskesmas Rawat Inap Kabupaten Pasuruan. Umur merupakan faktor yang paling berpengaruh terhadap pelaksanaan IMD di Puskesmas Kabupaten Pasuruan.
\end{abstract}

Kata Kunci: Bidan, faktor ekstrinsik, faktor intrinsik, Inisiasi Menyusu Dini (IMD)

\begin{abstract}
Early Initiation of Breastfeeding (EIB) is a natural process in which a baby starts to breastfeed soon after being placed in skin-to-skin contact with the mother within one hour after birth. Although EIB must be executed by a midwife in the birth process, but not all midwives carry it out properly. There are several intrinsic and extrinsic factors affecting ElB implementation. This study aims to determine intrinsic factors' effect including midwives characteristics (age, education, and tenure), knowledge, attitudes and motivation, and extrinsic factors including training, workload, and reward of Early Initiation of Breastfeeding implementation in Inpatient Health Center Pasuruan regency. This study uses an analytic observational research design with case control and purposive sampling technique. The research was conducted in three Inpatient Health Centers in Pasuruan regency, i.e. Health Center Gondangwetan, Purwodadi, and Winongan from November to December 2013. The sample size in this study was 40 people that were observed using observation sheet when implementing EIB then filling out a questionnaire to measure the intrinsic factors such as midwives characteristics (age, education, and tenure), knowledge, attitudes, and motivation and extrinsic factors including training, workload, and reward. Test result analysis of studies used path analysis. The study finds that midwives' intrinsic and extrinsic factors influence the EIB implementation in Inpatient Health Center Pasuruan. The variables that directly influence EIB implementation in Inpatient Health Center Pasuruan are midwives' attitude of (2,78\%), workload, i.e. the number of deliveries/week (0.26\%) and the number of midwives working hours/week (1,54\%) and motivation (0,44\%). Age (14,51\%), education (2\%), length of employment $(7,67 \%)$, knowledge $(0,26 \%)$, training $(8 \%)$, and reward $(0,06 \%)$ are indirect influential factors to the EIB implementation. Age is the most significant factor on the EIB implementation.
\end{abstract}

Keywords: Early Breastfeeding Initiation, extrinsicfactor, intrinsic factor, midwife

Jurnal Kedokteran Brawijaya, Vol. 28, No. 3, Februari 2015; Korespondensi: Rismaina Putri. Program Magister Kebidanan Fakultas Kedokteran Universitas Brawijaya, Jl.Veteran Malang Tel. (0341)569117 Email: rismaina.putri@gmail.com 


\section{PENDAHULUAN}

Setiap tiga menit, satu anak balita meninggal dunia. Data yang telah dirilis oleh United Nations of Children's Fund (UNICEF) tahun 2010, di Indonesia tercatat Angka Kematian Bayi (AKB) masih sangat tinggi yaitu $2 \%$ dari kematian bayi di seluruh dunia dan jumlah bayi yang meninggal adalah 17 tiap 1000 kelahiran hidup (1). Hal ini salah satunya dikarenakan pelaksanaan IMD di Indonesia belum terlaksana secara optimal dan dan pemberian ASI eksklusif tergolong rendah (2). Inisiasi Menyusu Dini (IMD) adalah proses alami saat bayi mulai menyusu sendiri segera setelah lahir. Hal ini terjadi jika segera setelah lahir, bayi dibiarkan kontak kulit dengan kulit ibunya, setidaknya selama 1 (satu) jam setelah lahir. Bayi melakukan inisiasi menyusu dini ini dinamakan merangkak mencari payudara atau the breast crawl (3).

Pemerintah Kabupaten Pasuruan telah menyusun peraturan mengenai pelaksanaan IMD dan ASI Eksklusif yang tertuang dalam Peraturan Daerah (Perda) Nomor 2 Tahun 2009 tentang Kesehatan Ibu, Bayi Baru Lahir dan Anak (KIBBLA). Dalam peraturan tersebut pada Bab V Pasal 7 menyebutkan bahwa Setiap Ibu melahirkan wajib memberikan IMD dan ASI Eksklusif sekurang-kurangnya selama enam (6) bulan tanpa diselingi makanan tambahan $(4,5)$. Peraturan tersebut tidak menjamin bahwa pelaksanaannya berhasil baik. Cakupan IMD dan ASI Eksklusif masih sangat rendah. Menurut Data Kesehatan Indonesia tahun 2011 tentang ASI eksklusif menunjukkan bahwa cakupan bayi yang diberikan ASI eksklusif di Propinsi Jawa Timur pada tahun 2010 cukup rendah yaitu sebesar $49,7 \%$, sedangkan di Kabupaten Pasuruan tahun 2010 menunjukkan cakupan yang sangat rendah yaitu $8,7 \%$. Jumlah ini masih dikatakan rendah jika dibandingkan dengan target pencapaian ASI eksklusif pada tahun 2010 yaitu $80 \%$ (6).

Pelaksanaan IMD dipengaruhi oleh faktor intrinsik dan ekstrinsik dari tenaga kesehatan (7). Faktor intrinsik ini meliputi pendidikan, pengalaman, pengetahuan, sikap, motivasi, usia, ketrampilan emosi, sedangkan faktor ekstrinsik meliputi kepemimpinan, kompensasi, fasilitas, pelatihan, beban kerja, sistem imbalan, dan hukuman (8) Keberhasilan program IMD sangat dipengaruhi oleh sikap, pengetahuan dan motivasi petugas kesehatan (dokter, bidan, perawat) yang pertama kali membantu ibu selama proses persalinan (9). Penolong persalinan akan melaksanakan praktik pelaksanaan IMD dengan baik dan benar jika penolong persalinan mempunyai pengetahuan yang baik tentang IMD (10). Pelatihan juga dibutuhkan bidan untuk memperbaiki dan meningkatkan pengetahuan dan sikap bidan terhadap program IMD(3). Oleh karena itu sikap, motivasi dan perilaku petugas kesehatan khususnya bidan yang didasari pengetahuan tentang IMD besar pengaruhnya terhadap keberhasilan praktek IMD (11).

Hasil studi pendahuluan yang dilakukan pada bulan April 2013 melalui wawancara terhadap 12 bidan di Puskesmas Rawat Inap Kabupaten Pasuruan, menunjukkan bahwa delapan bidan $(66,7 \%)$ selalu melaksanakan IMD pada setiap pertolongan persalinan yang dilakukan dan empat bidan $(33,3 \%)$ belum melaksanakan IMD sesuai tata langkah yang ada. Alasan yang dikemukaan adalah bayi akan dilakukan pengukuran antropometri meskipun belum mencapai puting susu ibu, pengetahuan bidan mengenai IMD adalah bayi diletakkan di dekat puting susu ibu agar bayi lebih cepat mencapai puting, alasan lain adalah bidan cukup repot menangani persalinan dan inisiasi menambah pekerjaan.

Penelitian ini bertujuan untuk mengetahui pengaruh faktor intrinsik yang meliputi karakteristik bidan (umur, pendidikan dan masa kerja), pengetahuan, sikap dan motivasi serta faktor ekstrinsik bidan meliputi pelatihan, beban kerja dan imbalan terhadap pelaksanaan IMD di Puskesmas Rawat Inap Kabupaten Pasuruan. Hasil penelitian diharapakan bermanfaat sebagai bahan studi lanjut dan bahan kajian tentang IMD, sebagai bahan masukan dalam pelaksanaan pembinaan dan pengambilan kebijakan terhadap hal-hal yang berkaitan dengan pelaksanaan IMD serta meningkatkan kualitas asuhan kebidanan dalam pelaksanaan IMD dan ASI eksklusif.

\section{METODE}

Penelitian ini merupakan penelitian observasional analitik dengan cross sectional. Teknik pengambilan sampel dilakukan dengan purposive sampling. Penelitian dilakukan di tiga (3) Puskesmas Rawat Inap Kabupaten Pasuruan yaitu Puskesmas Gondangwetan, Purwodadi dan Winongan sejak bulan November-Desember 2013. Sampel dalam penelitian ini adalah bidan yang bekerja di Puskesmas Rawat Inap Kabupaten Pasuruan yaitu 40 bidan.

Variabel dalam penelitian ini adalah variabel eksogen yaitu faktor intrinsik yang meliputi karakteristik bidan (umur, pendidikan, masa kerja), serta faktor ekstrinsik yaitu pelatihan dan imbalan. Variabel endogen dalam penelitian ini yaitu faktor intrinsik yang meliputi pengetahuan, sikap dan motivasi, faktor ekstrinsik yaitu beban kerja dan pelaksanaan IMD.

Alat yang digunakan pada penelitian ini adalah kuisioner. Setiap responden diberikan penjelasan mengenai tujuan dan cara penelitian kemudian mengisi informed consent. Responden kemudian diobservasi sebanyak satu kali pada saat pelaksanaan IMD menggunakan lembar observasi berupa checklist yang berisi langkah-langkah pelaksanaan IMD kemudian dilakukan skoring dari langkah yang dilakukan bidan.

Selain itu dilakukan observasi kegiatan bidan selama satu minggu kemudian responden mengisi kuisioner yang berisi data-data mengenai faktor intrinsik bidan yang meliputi karakteristik bidan (umur, pendidikan, masa kerja), pengetahuan, sikap, dan motivasi serta faktor intrinsik yang meliputi pelatihan, beban kerja dan imbalan. Data hasil penelitian yang telah diolah kemudian dianalisis menggunakan analisis jalur (path analysis).

Hasil penelitian sebelumnya menunjukkan penolong persalinan akan melaksanakan IMD dengan baik dan benar jika penolong persalinan mempunyai pengetahuan yang baik tentang IMD (10). Karakteristik bidan seperti umur, pendidikan dan pengalaman yang didapatkan selama bekerja mempengaruhi pengetahuan (12). Pelatihan juga dibutuhkan bidan untuk memperbaiki dan meningkatkan pengetahuan \& sikap bidan terhadap program IMD (3). Sikap, motivasi, beban kerja dan perilaku petugas kesehatan yang didasari pengetahuan tentang IMD besar pengaruhnya terhadap keberhasilan praktik IMD (11). 


\section{HASIL}

Terdapat 33 puskesmas yang terbagi menjadi 20 unit Puskesmas Rawat Jalan dan 13 unit Puskesmas Rawat Inap pada wilayah studi. Dari 13 unit Puskesmas Rawat Inap, delapan diantaranya merupakan Puskesmas Pelayanan Obstetri Neonatal Emergensi Dasar (PONED) yaitu Puskesmas Grati, Lekok, Gondangwetan, Ngempit, Beji, Purwodadi, Winongan dan Pandaan.

\section{Gambaran Faktor Intrinsik, Ekstrinsik dan Pelaksanaan IMD oleh Bidan}

Hasil pada Tabel 1 menerangkan bahwa dari 40 responden terbanyak pada kelompok umur 31-40 tahun yaitu $(47,5 \%)$, pada variabel pendidikan dari 40 responden bidan terdapat $85 \%$ yang memiliki pendidikan D3 Kebidanan, dan variabel masa kerja menunjukkan sebagian besar $(57,5 \%)$ memiliki masa kerja $\leq 10$ tahun. Seluruh responden mempunyai pengetahuan, 55\% responden memiliki sikap mendukung terhadap IMD, dan sebagian besar memiliki motivasi yang kurang terhadap $\operatorname{IMD}(62,5 \%)$.

Berdasarkan faktor ekstrinsik bidan, dari 40 responden sebagian besar pernah mengikuti pelatihan yang berhubungan dengan IMD (65\%), pada variabel beban kerja berdasarkan lama kerja bidan per minggu hampir seluruhnya bekerja tidak efektif per minggu (80\%) dan sebagian besar menangani $\leq 2$ ibu bersalin per minggu (55\%). Berdasarkan variabel imbalan sebagian besar (70\%) memliki imbalan yang kurang. Pelaksanaan IMD di Puskesmas rawat inap Kabupaten Pasuruan menunjukkan bahwa dari 40 responden sebagian besar (70\%) memiliki skor 91 hingga 100.

Tabel 1. Distribusi frekuensi responden berdasarkan faktor intrinsik, ekstrinsik bidan dan pelaksanaan IMD di puskesmas rawat inap kabupaten Pasuruan

\begin{tabular}{|c|c|c|c|}
\hline & Variabel & $\begin{array}{l}\text { Frekuensi } \\
\text { (f) }\end{array}$ & $\begin{array}{c}\text { Prosentase } \\
\text { (\%) }\end{array}$ \\
\hline \multirow[t]{27}{*}{1.} & $\begin{array}{l}\text { Faktor Intrinsik Bidan } \\
\text { a. Karakteristik Bidan } \\
\text { Umur }\end{array}$ & & \\
\hline & $20-30$ tahun & 13 & 32,5 \\
\hline & $31-40$ tahun & 19 & 47,5 \\
\hline & $41-50$ tahun & 8 & 20 \\
\hline & Total & 40 & 100 \\
\hline & Pendidikan & & \\
\hline & D1 Kebidanan & 2 & 5 \\
\hline & D3 Kebidanan & 34 & 85 \\
\hline & D4/S1 Kebidanan & 4 & 10 \\
\hline & Total & 40 & 100 \\
\hline & Masa Kerja & & \\
\hline & $\leq 10$ tahun & 23 & 57,5 \\
\hline & $11-20$ tahun & 12 & 30 \\
\hline & $\geq 21$ tłuun & 5 & 12,5 \\
\hline & Total & 40 & 100 \\
\hline & b. Pengetahuan & & \\
\hline & Baik & 40 & 100 \\
\hline & Kurang & 0 & 0 \\
\hline & Total & 40 & 100 \\
\hline & c. Sikap & 22 & 55 \\
\hline & Mendukung & 18 & 45 \\
\hline & Tidak Mendukung & & \\
\hline & Total & 40 & 100 \\
\hline & d. Motivasi & & \\
\hline & Baik & 15 & 37,5 \\
\hline & Kurang & 25 & 62,5 \\
\hline & Total & 40 & 100 \\
\hline
\end{tabular}

Tabel 1. Distribusi frekuensi responden berdasarkan faktor intrinsik, ekstrinsik bidan dan pelaksanaan IMD di puskesmas rawat inap kabupaten Pasuruan (lanjutan)

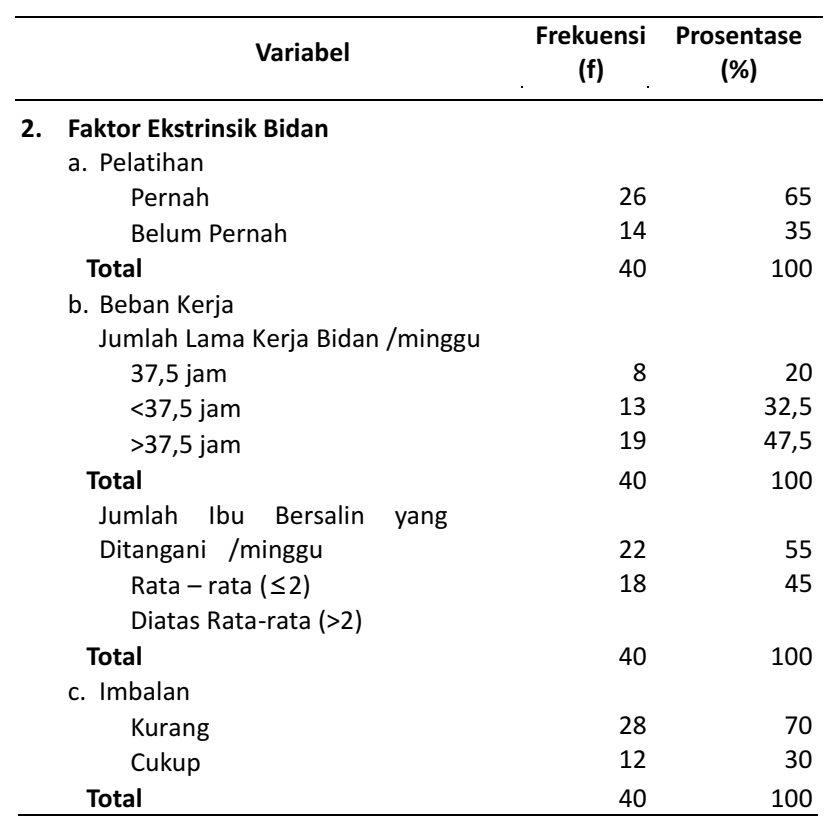

\section{Analisis Jalur}

Berdasarkan kerangka konsep penelitian diagram analisis jalur disajikan pada Gambar 1.

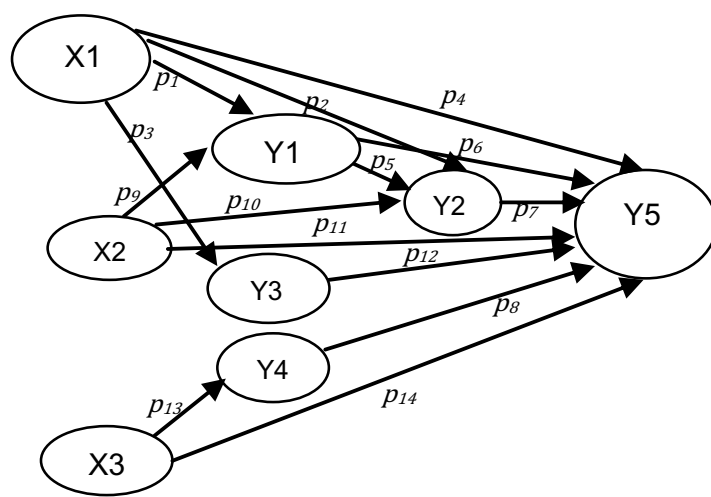

Gambar 1. Diagram analisis jalur

Keterangan:

X1 = Karakteristik Bidan (umur, pendidikan, masa kerja)

$\mathrm{X} 2$ = Pelatihan

$\mathrm{X} 3=$ Imbalan

$\mathrm{Y} 1$ = Pengetahuan

$\mathrm{Y} 2=$ Sikap

Y3 = Beban Kerja

$\mathrm{Y} 4=$ Motivasi

Y5 = Pelaksanaan IMD

Berdasarkan diagram pada Gambar 1 didapatkan lima (5) persamaan jalur. Perhitungan koefisien jalur di semua jalur baik secara simultan atau individual didapatkan nilai sig $<0,05$ yang menunjukkan pengaruh signifikan antar variabel. Lima persamaan jalur berdasarkan diagram jalur di atas adalah: 
1) Pengetahuan $=\alpha_{0}+\alpha_{1}$ karakteristik bidan $+\alpha_{2}$ pelatihan

2) Sikap $=b_{0}+b_{1}$ karakteristik bidan $+b_{2}$ pengetahuan $+b_{3}$ pelatihan

3) Beban kerja $=\nu_{0}+\nu_{1}$ karakteristik bidan

d) Motivasi $=\omega_{0}+\omega_{1}$ imbalan

e) IMD $=\delta_{0}+\delta_{1}$ karakteristik bidan $+\delta_{2}$ pengetahuan $+\delta_{3}$ sikap $+\delta_{4}$ motivasi $+\delta_{5}$ pelatihan $+\delta_{6}$ beban kerja $+\delta_{7}$ imbalan

Hasil uji persamaan jalur 1 menunjukkan bahwa 81,5\% pengetahuan bidan dipengaruhi faktor lain selain karakteristik bidan dan pelatihan yang tidak dapat dijelaskan dalam penelitian. Pada persamaan jalur 2 menunjukkan bahwa76,2\% sikap bidan dipengaruhi kontribusi faktor lain selain karakteristik bidang, pengetahuan dan pelatihan yang tidak dapat dijelaskan dalam penelitian. Perhitungan koefisien jalur 3 tentang beban kerja dibagi menjadi 2 yaitu berdasarkan variabel $\Sigma$ jam kerja/minggu dan $\Sigma$ persalinan/minggu. Berdasarkan jam kerja per minggu, $94,1 \%$ beban kerja bidan dipengaruhi faktor lain yang tidak dapat dijelaskan dalam penelitian dan berdasarkan jumlah persalinan/minggu $89,8 \%$ dipengaruhi faktor lain yang tidak dapat dijelaskan dalam penelitian. Motivasi bidan untuk melakukan IMD sebanyak $73,5 \%$ dipengaruhi oeh faktor lain selain imbalan yang tidak dijelaskan dalam model. Pada uji persamaan jalur kelima menunjukkan bahwa $92 \%$ pelaksanaan IMD oleh Bidan dipengaruhi faktor lain yang tidak dapat dijelaskan dari penelitian ini.

Tabel 2 menunjukkan pada jalur 1 faktor umur, pendidikan, masa kerja dan pelatihan mempengaruhi pengetahuan bidan mengenai IMD. Faktor masa kerja memiliki pengaruh terbesar terhadap pengetahuan bidan mengenai IMD $(30,14 \%)$ dan pengaruh terkecil terhadap pengetahuan bidan didapatkan oleh faktor pelatihan yaitu $3,06 \%$. Analisa model jalur 1 didapatkan bertambahnya umur bidan, pendidikan bidan yang semakin tinggi, masa kerja yang semakin lama dan bertambahnya keikutsertaan bidan mengikuti pelatihan menyebabkan pengetahuan bidan mengenai IMD meningkat.

Analisis jalur 2 menunjukkan faktor umur, pendidikan, masa kerja, pengetahuan dan pelatihan mempengaruhi sikap bidan terhadap IMD. Faktor umur memiliki pengaruh terbesar terhadap sikap bidan terhadap IMD $(12,47 \%)$ sedangkan pengaruh terkecil terhadap sikap bidan mengenai IMD didapatkan oleh faktor pelatihan yaitu $0,05 \%$. Analisa model jalur 2 juga menunjukkan bahwa semakin bertambah umur dan masa kerja bidan, pendidikan, pengetahuan bidan dan semakin bertambahnya pelatihan yang diikuti bidan maka sikap seorang bidan terhadap IMD semakin baik.

Jalur 3 menunjukkan faktor pendidikan memiliki pengaruh terbesar terhadap beban kerja yaitu $\Sigma$ persalinan/minggu $(11,97 \%)$ sedangkan pengaruh terkecil terhadap beban kerja dalam hal $\Sigma$ jam kerja/minggu didapatkan oleh faktor masa kerja yaitu $0,92 \%$. Analisa model jalur 3 berdasarkan $\Sigma$ persalinan /minggu dapat diartikan bahwa umur bidan yang bertambah dan pendidikan bidan yang semakin maka $\Sigma$ persalinan yang ditangani/minggu semakin meningkat, sedangkan masa kerja bidan yang semakin lama menyebabkan $\Sigma$ persalinan yang ditanganinya/ minggu semakin berkurang. Berdasarkan $\Sigma$ jam kerja/minggu dapat diartikan bahwa bertambahnya umur dan masa kerja bidan maka semakin berkurang $\Sigma$ jam kerja bidan/minggu, sedangkan pendidikan bidan yang semakin tinggi menyebabkan $\Sigma$ jam kerja bidan/minggu meningkat. Pada jalur 4 menunjukkan imbalan yang didapatkan bidan berpengaruh terhadap motivasi bidan terhadap pelaksanaan IMD di Puskesmas Rawat Inap Kabupaten Pasuruan. Terdapat 4,62\% pengaruh imbalan terhadap motivasi bidan terhadap pelaksanaan IMD. Berdasarkan analisis model jalur 4 ini diartikan bahwa tingginya imbalan yang didapatkan bidan maka motivasi bidan terhadap pelaksanaan IMD semakin meningkat.

Jalur yang terakhir yaitu jalur 5 menunjukkan umur merupakan faktor yang memiliki pengaruh terbesar terhadap pelaksanaan IMD (14,51\%) dan faktor imbalan memiliki pengaruh terkecil terhadap pelaksanaan IMD yaitu $0,06 \%$. Analisa model jalur 5 dapat diartikan bahwa pertambahan umur bidan, keikutsertaan bidan mengikuti pelatihan yang berhubungan dengan IMD, $\Sigma$ jam kerja/minggu, $\Sigma$ persalinan/minggu dan imbalan meyebabkan pelaksanaan IMD meningkat. Semakin tinggi pendidikan yang dimiliki bidan, pengetahuan mengenai IMD, motivasi dan sikap bidan terhadap IMD yang semakin baik menyebabkan pelaksanaan IMD meningkat.

Tabel 2. Koefisien jalur faktor intrinsik dan ekstrinsik bidan yang mempengaruhi pelaksanaan IMD di puksmesmas rawat inap kabupaten Pasuruan

\begin{tabular}{|c|c|c|c|}
\hline Faktor & $\begin{array}{c}\text { Koefisien } \\
\text { Jalur }\end{array}$ & $p$ value & $\begin{array}{l}\text { Kontribusi } \\
\text { Pengaruh }\end{array}$ \\
\hline \multicolumn{4}{|l|}{ 1. Jalur 1} \\
\hline Masa Kerja-Pengetahuan & 0,549 & 0,048 & $30,14 \%$ \\
\hline Umur- Pengetahuan & 0,523 & 0,040 & $27,35 \%$ \\
\hline Pendidikan-Pengetahuan & 0,262 & 0,022 & $6,86 \%$ \\
\hline Pelatihan-Pengetahuan & 0,175 & 0,017 & $3,06 \%$ \\
\hline \multicolumn{4}{|l|}{ 2. Jalur 2} \\
\hline Umur - Sikap & 0,332 & 0,045 & $12,47 \%$ \\
\hline Pendidikan - Sikap & 0,228 & 0,038 & $5,47 \%$ \\
\hline Masa Kerja - Sikap & 0,210 & 0,037 & $4,62 \%$ \\
\hline Pengetahuan- Sikap & 0,024 & 0,046 & $1,69 \%$ \\
\hline Pelatihan - Sikap & 0,130 & 0,038 & $0,05 \%$ \\
\hline \multicolumn{4}{|l|}{ 3. Jalur 3} \\
\hline Umur - $\Sigma$ jam kerja/ mgg & $-0,107$ & 0,048 & $1,14 \%$ \\
\hline Pendidikan - $\Sigma$ jam kerja/ mgg & 0,276 & 0,018 & $7,61 \%$ \\
\hline Masa Kerja - $\Sigma$ jam kerja/ mgg & $-0,096$ & 0,020 & $0,92 \%$ \\
\hline Umur $-\Sigma$ persalinan/ mgg & 0,156 & 0,033 & $2,43 \%$ \\
\hline Pendidikan $-\Sigma$ persalinan/ mgg & 0,346 & 0,043 & $11,97 \%$ \\
\hline Masa Kerja $-\Sigma$ persalinan/ mgg & $-0,154$ & 0,032 & $2,37 \%$ \\
\hline \multicolumn{4}{|l|}{ 4. Jalur 4} \\
\hline Imbalan - Motivasi & 0,215 & 0,031 & $4,62 \%$ \\
\hline \multicolumn{4}{|l|}{ 5. Jalur 5} \\
\hline Umur-IMD & 0,372 & 0,048 & $14,51 \%$ \\
\hline Pelatihan - IMD & 0,274 & 0,017 & $8 \%$ \\
\hline Masa Kerja - IMD & 0,234 & 0,042 & $7,67 \%$ \\
\hline Sikap - IMD & 0,167 & 0,030 & $2,78 \%$ \\
\hline Pendidikan - IMD & 0,090 & 0,046 & $2 \%$ \\
\hline$\Sigma$ jam kerja/minggu - IMD & 0,124 & 0,016 & $1,54 \%$ \\
\hline Motivasi - IMD & 0,067 & 0,034 & $0,44 \%$ \\
\hline Pengetahuan - IMD & 0,047 & 0,038 & $0,26 \%$ \\
\hline$\Sigma$ persalinan/minggu $-I M D$ & 0,051 & 0,041 & $0,26 \%$ \\
\hline Imbalan - IMD & 0,011 & 0,025 & $0,06 \%$ \\
\hline
\end{tabular}

\section{DISKUSI}

Pengaruh Karakteristik Bidan dan Pelatihan terhadap Pengetahuan

Hasil penelitian menunjukkan bertambahnya umur bidan, tingginya pendidikan bidan, masa kerja bidan yang semakin lama dan pelatihan tentang IMD yang semakin 
sering diikuti bidan akan meningkatkan pengetahuan mengenai IMD. Masa kerja memiliki pengaruh terbesar terhadap baik tidaknya pengetahuan bidan mengenai IMD di Puskesmas Rawat Inap Kabupaten Pasuruan sebesar $30,14 \%$, diikuti faktor umur $(27,35 \%)$, pendidikan $(6,86 \%)$ dan yang terkecil adalah faktor pelatihan yaitu $3,06 \%$. Pengalaman yang diperoleh bidan dapat memperluas pengetahuan mengenai IMD(12). Penelitian menunjukkan bahwa semakin lama seseorang bekerja semakin banyak kasus yang ditanganinya sehingga pengetahuan dan pengalamannya semakin meningkat. Pengetahuan yang dimiliki bidan diperoleh dari pengalaman baik itu pengalaman dari dirinya sendiri maupun orang lain karena semakin lama bidan tersebut bekerja maka pengalaman yang diperoleh akan semakin banyak (13).

Selain masa kerja, pengetahuan bidan juga dipengaruhi oleh umur. Bertambahnya umur akan meningkatkan daya tangkap dan pola pikir bidan sehingga pengetahuan yang diperolehnya semakin membaik. Umur bidan yang berada dalam rentang 31 sampai 40 tahun termasuk dalam masa dewasa awal. Pada masa ini daya tangkap dan pola pikir bidan semakin berkembang sehingga dapat meningkatkan pengetahuan mengenai IMD (12). Semakin tua umur bidan maka makin tinggi tingkat pengetahuannya. Secara fisiologis pertumbuhan dan perkembangan seseorang dapat digambarkan dengan pertambahan umur. Dengan adanya peningkatan umur diharapkan kemampuan motorik dapat tumbuh sesuai dengan pertumbuhan dan perkembangannya yang diidentikkan dengan idealisme yang tinggi, tenaga yang prima dan semangat untuk belajar sesuatu yang baru(14).

Pengetahuan tentang IMD juga dipengaruhi oleh pendidikan. Bidan di Puskesmas Rawat Inap Kabupaten Pasuruan hampir seluruhnya berpendidikan D3. Bidan merupakan seseorang yang telah mengikuti pendidikan bidan yang diakui di negaranya, telah lulus dari pendidikan tersebut serta memenuhi kualifikasi untuk didaftar dan atau memuiliki lisesnsi untuk melakukan praktik bidan. Diploma merupakan pendidikan minimal yang harus ditempuh Bidan (15). Pendidikan bidan yang semakin tinggi meningkatkan pengetahuan yang dimiliki mengenai IMD. Hasil dari penelitian Huang \& Wu menunjukkan bahwa seorang perawat yang lebih lama menempuh pendidikan maka pengetahuannya lebih baik (16).

Dibandingkan dengan variabel yang lain, pelatihan memiliki pengaruh terkecil terhadap pengetahuan bidan Puskesmas Rawat Inap di Kabupaten Pasuruan. Sebagian besar bidan di Puskesmas Rawat Inap Kabupaten Pasuruan pernah mengikuti pelatihan yang berhubungan dengan IMD. kurangnya pengetahuan tenaga kesehatan berdampak terhadap optimalnya pelaksanaan proses menyusui pada ibu postpartum (17). Penelitian lain menunjukkan efek pelatihan akan kurang terlihat dan kurang berkelanjutan baik dalam pelaksanaannya bukan hanya dipengaruhi pengetahuan, namun disebabkan oleh pengalaman dan dukungan. Dalam hal ini dukungan yang dimaksud adalah dukungan dari rekan lain yang berpengalaman dan dukungan instansi (18).

Kecilnya pengaruh pelatihan mengenai IMD terhadap pelaksanaan IMD mungkin disebabkan oleh kecilnya keikutsertaan bidan Puskesmas yang mengikuti pelatihan. Berdasarkan informasi yang peneliti dapatkan saat pengambilan data, pelatihan yang diikuti oleh responden merupakan pelatihan yang hanya diadakan
Dinas Kesehatan Kabupaten Pasuruan. Hal ini dikarenakan pelatihan yang bukan diadakan oleh Dinkes Kabupaten Pasuruan tidak dapat dimasukkan ke dalam perhitungan kum untuk kenaikan pangkat. Responden tetap diperbolehkan mengikuti pelatihan yang diadakan selain dari Dinkes Kabupaten Pasuruan menggunakan dana pribadi.

Pengetahuan tidak saja dipengaruhi karakteristik bidan yang meliputi umur, pendidikan dan masa kerja namun juga kemungkinan besar dipengaruhi oleh faktor lain yang tidak terkaji dalam penelitian ini. Faktor lain yang mungkin mempengaruhi pengetahuan bidan adalah pekerjaan. jenis pekerjaan yang membutuhkan interaksi dengan orang lain menyebabkan pengetahuan pekerjanya lebih baik dibandingkan dengan jenis pekerjaan yang tidak membutuhkan interaksi dengan orang lain (19). Hal ini didukung sebuah penelitian saat seseorang bidan berinteraksi dengan orang lain, maka secara tidak langsung terjadi pertukaran informasi dari kedua orang. Bidan merupakan pekerjaan yang membutuhkan interaksi dengan orang lain seperti pasien, keluarga, tenaga kesehatan maupun masyarakat. Seringnya interaksi ini akan menambah pengetahuan yang diperoleh tersebut (20).

\section{Pengaruh Karakteristik Bidan, Pengetahuan dan Pelatihan} terhadap Sikap Bidan

Hasil penelitian menunjukkan pertambahan umur dan masa kerja bidan, pendidikan bidan yang semakin tinggi, pengetahuan bidan mengenai IMD yang semakin baik, serta meningkatnya keikutsertaan bidan dalam pelatihan mengenai IMD mempengaruhi sikap bidan untuk mendukung IMD. Karakteristik bidan (umur, pendidikan, masa kerja), pengetahuan dan pelatihan berpengaruh terhadap sikap bidan mengenai IMD. Sikap bidan Puskesmas Rawat Inap di Kabupaten Pasuruan paling besar dipengaruhi oleh faktor umur yaitu sebesar (12,47\%) diikuti pendidikan $(5,47 \%)$, masa kerja $(4,62 \%)$ dan pengetahuan $(1,69 \%)$, sedangkan pengaruh terkecil didapatkan oleh faktor pelatihan yaitu 0,05\%.

Umur merupakan faktor yang memiliki pengaruh terhadap sikap bidan di Puskesmas Rawat Inap Kabupaten Pasuruan. Sebagian besar bidan berumur 31-40 tahun. Rentang umur ini termasuk dalam masa dewasa awal dimana manusia mulai dihadapkan pada hal-hal yang berhubungan dengan tanggung jawab dan tingkat kesulitan yang lebih besar dibandingkan masa remaja. Umur 18-40 tahun dikatakan pada masa dewasa awal dimana pada masa ini manusia mulai dihadapkan pada tugas yang membutuhkan tanggung jawab besar, tingkat kesulitan yang dihadapi lebih besar dan mengacu pada aturan \& hukum yang berlaku dan disepakati bersama. Hal ini menunjukkan bahwa seharusnya pada rentang umur 31-40 tahun bidan akan lebih bertanggung jawab, lebih tertib, lebih bermoral terhadap kinerja (19). Teori tersebut didukung dengan penelitian bahwa seseorang yang lebih muda dan lebih berpendidikan memiliki sikap yang lebih liberal. Sikap yang lebih liberal dalam hal ini adalah lebih terbuka dalam menerima program IMD (20), bidan bersikap positif terhadap pelaksanaan IMD (21).

Faktor lain yang juga mempengaruhi sikap adalah pendidikan, masa kerja, pelatihan dan pengetahuan. seseorang yang menempuh pendidikan formal diajarkan dasar pengertian konsep moral dalam individu. Pemahaman mengenai baik dan buruk, garis pemisah 
antara sesuatu yang boleh dan yang tidak boleh diperoleh dari pendidikan (22). Pendidikan mempengaruhi proses belajar, semakin tinggi pendidikan seseorang maka semakin mudah seseorang menerima informasi (12). Sebuah penelitian menyatakan perawat membutuhkan dukungan pendidikan untuk menumbuhkan sikap yang lebih positif terhadap promosi menyusui di kalangan ibu remaja (23). Hal ini didukung oleh sebuah penelitian bahwa perawat dengan tingkat pendidikan yang tinggi memiliki komponen promosi kesehatan masyarakat yang lebih kuat (24).

Masa kerja juga mempengaruhi sikap bidan terhadap IMD. Sebagian besar bidan memiliki masa kerja $\leq 10$ tahun. Konseling dan pendidikan yang tepat mengenai praktik pemberian ASI dapat dilakukan untuk mencapai perubahan sikap, persepsi, pengetahuan dan pelaksanaan ASI eksklusif. Hal ini didukung teori yang mengatakan bahwa tidak adanya pengalaman sama sekali dengan suatu objek cenderung akan membentuk sikap negatif terhadap objek tersebut (22).

Pengaruh masa kerja terhadap sikap pada dasarnya berhubungan dengan pengalaman. Apa yang telah dan sedang dialami bidan akan ikut membentuk dan mempengaruhi penghayatan terhadap IMD. Masa kerja $\leq$ 10 tahun sebenarnya merupakan pembagian masa kerja paling sedikit dibandingkan kategori yang lain dalam penelitian ini. Bukan berarti dalam masa $<10$ tahun bidan tersebut sama sekali tidak memiliki pengalaman terhadap IMD. Pengalaman dalam masa kerja tersebut mungkin menjadi faktor yang menyebabkan sikap yang mendukung terhadap IMD. Data deskriptif menunjukkan seluruh bidan di Puskesmas Rawat Inap Kabupaten Pasuruan berpengetahuan baik mengenai IMD dan sebagian besar diantaranya pernah mengikuti pelatihan yang berhubungan dengan IMD. Tujuan pelatihan adalah mengembangkan keahlian sehingga pekerjaan dapat diselesaikan dengan lebih cepat dan lebih efektif, mengembangkan pengetahuan, sehingga pekerjaan dapat diselesaikan secara rasional, dan mengembangkan sikap, sehingga menimbulkan kemauan kerjasama dengan teman-teman pegawai dan dengan pimpinan (25). pelatihan yang berbasis fasilitas fisik dan kursus untuk penyegaran harus ditawarkan pada semua fasilitas nonterakreditasi, terutama yang berkaitan dengan keterampilan praktis yang diperlukan staf perawat (26).

Dalam penelitian ini, $70 \%$ bidan mengatakan tidak ada penghargaan ataupun imbalan dalam pelaksanaan IMD. Hal ini dapat menjadi evaluasi bagi pemerintah maupun instansi kesehatan yang terkait untuk meningkatkan dukungan kepada tenaga kesehatan dalam pelaksanaan IMD melalui pemberian imbalan. Puskesmas wajib menawarkan pelatihan mengenai IMD untuk bidan yang bekerja di kamar bersalin agar membentuk sikap postiif sehingga bidan mendukung pelaksanaan IMD.

Sikap tidak saja dipengaruhi karakteristik bidan yang meliputi umur, pendidikan, masa kerja serta pengetahuan namun juga kemungkinan besar dipengaruhi oleh faktor lain yang tidak terkaji dalam penelitian ini. Sebesar $76,2 \%$ sikap dipengaruhi oleh faktor lain yang tidak dapat dijelaskan dalam penelitian. Faktor lain yang mungkin mempengaruhi sikap bidan tentang IMD adalah kebudayaan, orang lain yang dianggap penting dan media massa. Pembentukan sikap tergantung kepada kebudayaan tempat individu tersebut dibesarkan (22). kebudayaan mempengaruhi sikap seorang bidan dalam mendukung IMD. Di Sumatera Barat Bidan masih belum sepenuhnya mendukung IMD dikarenakan pengaruh belum keluarnya ASI pada awal-awal proses menyusui, mereka cenderung memberikan susu formula untuk membantu bayi mendapatkan asupan nutrisi di awal kehidupan (27).

\section{Pengaruh Karakteristik Bidan terhadap Beban Kerja}

Karakteristik bidan (umur, pendidikan, masa kerja) berpengaruh terhadap beban kerja bidan di Puskesmas Rawat Inap Kabupaten Pasuruan. Beban kerja dalam penelitian ini menggunakan indikator $\Sigma$ jam kerja/minggu dan $\Sigma$ persalinan yang ditangani bidan/minggu. Hasil penelitian menunjukkan bertambahnya umur dan masa kerja bidan maka $\Sigma$ jam kerja bidan/minggu semakin berkurang. Sedangkan pendidikan seorang bidan semakin tinggi maka $\Sigma$ jam kerja seorang bidan/minggu semakin meningkat. Umur yang semakin bertambah dan pendidikan seorang bidan yang semakin tinggi menyebabkan $\Sigma$ persalinan yang ditangani/minggu meningkat, masa kerja bidan yang semakin lama menyebabkan $\Sigma$ persalinan yang ditangani bidan/minggu semakin berkurang.

Hasil penelitian menunjukkan pendidikan berpengaruh besar terhadap beban kerja yaitu $\Sigma$ persalinan/minggu (11,97\%) sedangkan masa kerja berpengaruh kecil terhadap beban kerja dalam hal $\Sigma$ jam kerja/minggu dibandingkan faktor yang lain dalam jalur $3(0,92 \%)$. Salah satu faktor yang dapat meningkatkan produktifitas atau kinerja perawat adalah pendidikan formal perawat. Pendidikan memberikan pengetahuan bukan saja yang langsung dengan pelaksanaan tugas, tetapi juga landasan untuk mengembangkan diri serta kemampuan memanfaatkan semua sarana yang ada di sekitar kita untuk kelancaran tugas, semakin tinggi pendidikan semakin tinggi pula produktivitas kerja (28).

Pendidikan berpengaruh terhadap beban kerja juga didukung oleh sebuah penelitian bahwa semakin tinggi pendidikan seseorang maka tugas yang diberikan oleh atasan meningkat sehingga beban kerja juga meningkat (29). Tingginya pendidikan yang dimiliki bidan Puskesmas rawat inap di Kabupaten Pasuruan membuat beban kerja dalam hal jumlah jam kerja/minggu maupun jumlah persalinan/minggu meningkat, hal ini dikarenakan bidan mendapatkan kepercayaan bahwa bidan akan mampu menyelesaikan tugas lebih baik dibandingkan bidan yang pendidikannya lebih rendah sehingga pekerjaan yang diberikan menjadi lebih banyak.

Hal yang berbeda ditunjukkan oleh pengaruh masa kerja terhadap beban kerja. Masa kerja ternyata memiliki pengaruh paling kecil terhadap beban kerja. Masa kerja bidan yang semakin lama menyebabkan jumlah jam kerja/minggu dan jumlah persalinan yang ditangani/minggu berkurang. Masa bekerja merupakan hasil penyerapan dari berbagai aktivitas manusia, sehingga mampu menumbuhkan keterampilan dalam menyelesaikan pekerjaan. Masa bekerja seseorang berkaitan dengan pengalaman kerjanya. Karyawan yang telah lama bekerja pada perusahaan tertentu akan mempunyai berbagai pengalaman yang berkaitan dengan bidangnya masing-masing baik yang berkaitan dengan pekerjaan atau tugas-tugasnya maupun dengan permasalahan-permasalahan yang dapat muncul pada saat melaksanakan tugasnya (30). 
Masa kerja yang berhubungan dengan pengalaman yang didapatkan bidan mengenai IMD memiliki pengaruh kecil terhadap beban kerja. Hal ini didukung oleh penelitian yang menunjukkan bahwa beban kerja berat merupakan hambatan, bukan hanya untuk bidan yang baru lulus namun juga staf berpengalaman dalam usaha untuk mematuhi 10 langkah keberhasilan menyusui (31). Bidan yang memiliki masa kerja yang lama mempengaruhi berkurangnya jumlah jam kerja/minggu. Semakin lama masa kerja akan menambah pengalaman bidan sehingga bidan mampu menyelesaikan tugas lebih cepat dan tepat dibandingkan bidan yang memiliki masa kerja lebih sedikit. Masa kerja juga mempengaruhi berkurangnya jumlah persalinan yang ditangani/minggu. $\mathrm{Hal}$ ini disebabkan semakin lama masa kerja maka semakin senior bidan tersebut. sehingga pekerjaan yang dibebankan bidan lebih banyak dalam hal administratif dan sebagai pembimbing bidan yang lebih muda. Pertambahan umur bidan menyebabkan berkurangnya jumlah jam kerja seorang bidan. Hal ini disebabkan meskipun semakin tua umur bidan, kesiapan bidan dalam menyelesaikan pekerjaan akan berjalan lebih baik, makin bertanggung jawab terhadap tugas yang diberikan berdasarkan aturan yang berlaku sehingga bidan akan menyelesaikan pekerjaan lebih cepat dan tepat. Umur bidan dan masa kerja bidan meskipun berpengaruh terhadap beban kerja bidan, namun memiliki pengaruh yang kecil dibandingkan variabel lain.

Beban kerja akan tetap dialami oleh bidan meskipun bidan tersebut memiliki masa kerja yang pendek ataupun panjang. Semakin bertambah umur seorang bidan maka kinerja bidan di puskesmas Rawat inap Kabupaten Pasuruan semakin baik dan bertanggung jawab. Beban kerja tidak saja dipengaruhi karakteristik bidan yang meliputi umur, pendidikan dan masa kerja namun dipengaruhi oleh faktor lain yang tidak terkaji dalam penelitian ini. Faktor lain yang mungkin mempengaruhi beban kerja adalah stres. Stres merupakan respon tubuh yang bersifat tidak spesifik terhadap setiap tuntutan atau beban atasnya (32). Sebuah penelitian mengenai stres menunjukkan manifestasi dari stres kerja perawat antara lain akibat karakterisasi pasien, pengkajian terhadap pasien, dan aspek lingkungan kerja yang mengganggu merupakan langkah awal dalam menangani masalahmasalah yang datang mengenai tingkat kepadatan ruangan emergency, efisiensi pelaksanaan tugas, serta adanya tuntutan untuk menyelamatkan pasien (29).

\section{Pengaruh Imbalan terhadap Motivasi}

Hasil penelitian menunjukkan imbalan berpengaruh signifikan terhadap motivasi bidan. Imbalan yang semakin tinggi didapatkan bidan akan meningkatkan motivasi bidan terhadap pelaksanaan IMD. Sebagian besar bidan memiliki motivasi yang kurang terhadap IMD dan sebagian besar responden merasa memliki imbalan yang kurang. Motivasi seseorang akan sangat ditentukan oleh stimulusnya, stimulus tersebut meliputi kinerja, penghargaan, tantangan, tanggung jawab, pengembangan, keterlibatan dan kesempatan (33). Manusia pada dasarnya memiliki beberapa kebutuhan dasar, salah satunya adalah kebutuhan atas penghargaan (the esteem needs)(34). Sebuah penelitian menunjukkan perusahaan dapat mendorong karyawan untuk termotivasi bertugas lebih spesifik adalah dengan menerapkan imbalan yang terkait dengan kinerja.
Pengakuan lisan dan tulisan, pengakuan simbolis dan pengakuan sosial adalah motivator yang terkuat jika digunakan dengan benar (35).

Imbalan menjadi faktor yang mempengaruhi motivasi bidan puskesmas rawat inap kabupaten Pasuruan tentang IMD karena pada dasarnya manusia termotivasi oleh banyak kebutuhan dimana salah satunya adalah kebutuhan akan penghargaan. Kurangnya motivasi juga dimungkinkan ketidaktahuan bidan terhadap peraturan pelaksanaan IMD yang sudah tercantum dalam Peraturan Daerah (Perda), hal ini diketahui saat peneliti melakukan pengambilan data terdapat beberapa bidan yang menanyakan hal tersebut.

Imbalan yang dimaksud bisa secara langsung misalnya dalam bentuk gaji, insentif, dan bonus, komisi ataupun imbalan tidak langsung (tunjangan) dan ganjaran non finansial seperti jam kerja yang fleksibel dan kesempatan melanjutkan pendidikan. Seseorang akan memiliki motivasi yang baik jika tersedia imbalan yang sesuai dengan pekerjaan yang dilakukan. Meskipun IMD merupakan kegiatan yang wajib dilakukan dalam penatalaksanaan persalinan, namun instansi yang bersangkutan harus memahami pentingnya imbalan untuk meningkatkan motivasi karyawannya.

Meskipun imbalan mempengaruhi motivasi bidan mengenai IMD namun ternyata $73,5 \%$ motivasi bidan terhadap pelaksanaan IMD dipengaruhi oleh faktor lain yang tidak terkaji dalam penelitian ini. Salah satu faktor yang mungkin mempengaruhi motivasi bidan selain imbalan adalah rasa tanggung jawab dan dedikasi bidan terhadap profesinya sehingga meskipun bidan tersebut tidak mendapatkan imbalan untuk melakukan IMD, bidan tersebut tetap merasa bahwa pelaksanaan IMD merupakan tanggung jawabnya sebagai bidan. Faktor lain yang mungkin mempengaruhi motivasi adalah pekerjaan yang monoton. Motivasi seseorang ditentukan oleh stimulusnya. Stimulus tersebut meliputi kinerja, penghargaan, dan kesempatan. Manusia memiliki kebutuhan untuk berprestasi, saat seseorang bekerja tanpa menemui tantangan maka akan muncul rasa bosan(36). Rendahnya motivasi dapat disebabkan oleh faktor intrinsik seperti bosan dan jenuh terhadap pekerjaan karena tidak adanya variasi dalam pekerjaan dan monoton (37).

\section{Pengaruh Faktor Intrinsik dan Ekstrinsik terhadap pelaksanaan IMD}

Faktor intrinsik dan ekstrinsik bidan mempengaruhi pelaksanaan IMD di Puskesmas Rawat inap Kabupaten Pasuruan. Faktor intrinsik bidan ini meliputi karakteristik bidan, pengetahuan, sikap dan motivasi. Faktor ekstrinsik bidan meliputi pelatihan, beban kerja dan imbalan. Karakteristik bidan dalam penelitian ini menggunakan indikator umur, pendidikan dan masa kerja, kemudian pengetahuan, sikap dan motivasi. Sedangkan faktor ekstrinsik bidan meliputi pelatihan, beban kerja dan imbalan. Beban kerja dalam penelitian ini didasarkan pada dua hal yaitu $\Sigma$ jam kerja bidan/minggu dan $\Sigma$ persalinan yang ditangani bidan/minggu.

Hasil penelitian menunjukkan bertambahnya umur, pelatihan yang semakin sering diikuti, peningkatan jumlah jam kerja/minggu dan jumlah persalinan/minggu serta bertambahnya imbalan seorang bidan, menyebabkan pelaksanaan IMD semakin meningkat. Tingginya 
pendidikan, pengetahuan dan motivasi bidan, serta semakin baik sikap seorang bidan maka pelaksanaan IMD di Puskesmas Rawat Inap Kabupaten Pasuruan meningkat. Tinggi rendahnya pelaksanaan IMD di Puskesmas rawat Inap kabupaten Pasuruan paling besar dipengaruhi faktor umur bidan (14,51\%), diikuti pelatihan (8\%) dan masa kerja $(7,67 \%)$, sikap mengenai IMD $(2,78 \%)$, pendidikan $(2 \%)$, beban kerja, dan motivasi $(0,44 \%)$, sedangkan imbalan memiliki pengaruh paling kecil yaitu sebesar $0,06 \%$.

Inisiasi Menyusu Dini merupakan tindakan yang wajib dilakukan tenaga kesehatan dalam pertolongan persalinan setelah bayi lahir baik itu jenis persalinan normal maupun Sectio Caessaria. Dalam kondisi persalinan normal IMD dilakukan dalam 30 menit hingga satu jam pasca persalinan sedangkan jika seorang ibu melahirkan secara sectio caesaria maka IMD dilakukan 30 menit setelah ibu sadar. Hal ini tertuang dalam Peraturan Menteri Pemberdayaan Perempuan dan Perlindungan Anak Republik Indonesia Nomor 03 tahun 2010 mengenai 10 (sepuluh) langkah menuju keberhasilan pemberian ASI.

Masa dewasa awal dimulai pada umur 18 tahun sampai kira-kira umur 40 tahun, saat perubahan-perubahan fisik dan psikologis yang menyertai dan berkurangnya kemampuan reproduktif. Pada masa ini manusia mulai dihadapkan pada tugas yang membutuhkan tanggung jawab besar dan mengacu pada aturan \& hukum yang berlaku dan disepakati bersama (19). Umur tenaga kesehatan berperan terhadap pelaksanaan IMD dan ASI Eksklusif. Pada umur 24-35 tahun merupakan umur yang produktif, tenaga kesehatan memiliki idealisme tinggi dalam melaksanakan IMD dan ASI eksklusif sesuai dengan kebijakan yang berlaku. Penelitian lain menjelaskan pada umur produktif perawat/tenaga kesehatan memiliki kinerja yang lebih optimal dibandingkan dengan yang telah berumur di atas itu (2). Besarnya pengaruh umur terhadap pelaksanaan IMD oleh bidan di Puskesmas Rawat Inap Kabupaten Pasuruan disebabkan sebagian besar bidan berumur antara 31-40 tahun. Pada masa ini bidan dapat melaksanakan pekerjaan dengan penuh tanggung jawab terhadap tugas yang diberikan sehingga bidan melaksanakan IMD dengan baik dan optimal sesuai aturan yang berlaku.

Pelatihan mempengaruhi pelaksanaan IMD di Puskesmas Rawat Inap Kabupaten Pasuruan. pelatihan adalah suatu usaha untuk meningkatkan kemampuan sesuai dengan kebutuhan pekerjaan (38). Pernyataan ini didukung sebuah penelitian bahwa pengetahuan dan keterampilan selalu berkembang setiap waktu. Oleh karena itu, pelatihan menyusui dimana terdapat materi IMD di dalamnya penting dalam hal mendapatkan pengetahuan baru dan keterampilan. Dengan pelatihan, tenaga kesehatan bisa langsung mendidik ibu dan anggota keuarga dengan pengetahuan yang relevan dan komprehensif. Pelatihan penting untuk pelaksanaan IMD karena pelatihan bertujuan untuk meningkatkan pengetahuan dan sikap terhadap pelaksanaan program IMD. Bidan yang mengikuti pelatihan IMD pengetahuannya akan meningkat dan sikapnya akan mendukung program IMD (27).

Karakteristik bidan yang lain adalah masa kerja. Masa kerja erat kaitannnya dengan pengalaman seorang bidan dalam pelaksanaan IMD. pengalaman dapat diperoleh dari pengalaman sendiri maupun orang lain. Pengalaman yang sudah diperoleh dapat memperluas pengetahuan seseorang (12). Hal ini didukung penelitian bahwa dokter anak dengan pengalaman pribadi menyusui memiliki informasi yang lebih banyak dan kepercayaan diri yang lebih. Pengalaman pribadi merupakan prediktor kepercayaan dalam proses menyusui. Selain itu mereka yang menghadiri pelatihan tentang menyusui dinilai memiliki rasa percaya diri yang lebih dan kemampuan yang baik dalam mengelola masalah menyusui (39).

Semakin lama seseorang bekerja semakin banyak kasus yang ditanganinya sehingga semakin meningkat pengalamannya, sebaliknya semakin singkat orang bekerja maka semakin sedikit kasus yang ditanganinya. Pengalaman bekerja banyak memberikan keahlian dan keterampilan kerja. Masa kerja bidan di Puskesmas Rawat Inap Kabupaten Pasuruan memang sebagian besar $\leq 10$ tahun dan merupakan pembagian masa kerja paling sedikit dibandingkan kategori yang lain dalam penelitian ini, namun bukan berarti bahwa bidan tersebut sama sekali tidak memiliki pengalaman terhadap IMD sehingga meskipun masa kerja ini dianggap peling sedikit namun pengalaman yang didapatkan setidaknya mampu mempengaruhi pengetahuan bidan terhadap pelaksanaan IMD.

Variabel lain yang berpengaruh terhadap pelaksanaan IMD adalah pendidikan, pengetahuan, sikap, motivasi, beban kerja, dan imbalan. pengetahuan erat hubungannya dengan pendidikan, seseorang yang pendidikannya tinggi maka semakin luas pengetahuannya (19). Penelitian lain menyatakan rendahnya pendidikan dan kurangnya pengetahuan tenaga kesehatan berdampak terhadap optimalnya pelaksanaan proses menyusui (17). Pendidikan yang dimiliki bidan jika semakin tinggi maka pelaksanaan IMD juga semakin meningkat. Pendidikan yang tepat akan akan membantu bidan mendapatkan informasi mengenai IMD secara otomatis akan mengubah sikap, pengetahuan, pengalaman bidan terhadap IMD menjadi lebih baik. Pendidikan akan meningkatkan pengetahuan bidan karena bidan yang berpendidikan tinggi akan mendapatkan informasi lebih luas dibandingkan sesorang yang menempuh pendidikan yang lebih rendah. Semakin banyak informasi yang didapatkan otomatis semakin banyak pula pengetahuan yang dimiliki bidan tersebut sehingga IMD juga akan terlaksana dengan semakin baik.

Keberlangsungan program IMD membutuhkan pengetahuan yang baik, sikap dan motivasi yang kuat dari bidan (3). Hal ini didukung oleh penelitian bahwa pengetahuan, keterampilan dan sikap tenaga kesehatan sangat penting dalam rangka mendukung praktek pemberian ASI, termasuk menyusui dini. Para petugas kesehatan harus memiliki pengetahuan yang akurat tentang menyusui. Pengetahuan dapat diperoleh melalui pendidikan formal. Jika petugas kesehatan memiliki pengetahuan yang baik tentang menyusui dini, pengetahuan ini bersama-sama dengan keterampilan yang sesuai dapat menyebabkan sikap yang baik terhadap dukungan menyusui dini (7).

Sikap, motivasi dan perilaku petugas kesehatan khususnya bidan yang didasari pengetahuan tentang IMD besar pengaruhnya terhadap keberhasilan praktek IMD (11). Hal ini sejalan dengan penelitian mengenai ASI eksklusif bahwa konseling dan pendidikan yang tepat tentang praktek pemberian ASI yang diinginkan dapat dilakukan 
untuk mencapai perubahan sikap, persepsi, pengetahuan dan praktek ASI eksklusif, dukungan mutu yang tidak memadai dari penyedia layanan kesehatan, seperti yang digambarkan oleh pengalaman perawat, bisa menjadi tantangan (20).

Sebagian besar responden memiliki sikap mendukung terhadap IMD. Bidan yang memiliki sikap mendukung terhadap IMD akan melaksanakan IMD sesuai dengan aturan yang berlaku. bidan yang bersikap positif akan lebih besar kemungkinannya untuk melakukan IMD. Sikap positif bidan terhadap IMD antara lain adalah bidan merasa senang bila ibu mengerti akan pentingnya IMD, bidan mau menyebarluaskan informasi tentang pentingnya IMD, bidan mau membantu melaksanakan IMD, dan bidan tidak mau memberikan susu botol kepada bayi (2).

Beban kerja mempengaruhi pelaksanaan IMD beban kerja yang berlebihan dapat menimbulkan kelelahan baik fisik maupun mental dan menurunkan produktivitas kerja (37). Rasa frustasi dengan peningkatan beban kerja membuat perawat kesulitan menemukan waktu untuk melaksanakan asuhan sayang bayi secara efektif (26). Berdasarkan pengaruh $\Sigma$ jam kerja/minggu, peningkatan beban kerja membuat bidan kesulitan melaksanakan IMD. Selain itu $\Sigma$ persalinan yang ditangani/minggu menunjukkan bahwa bidan akan memiliki banyak kesempatan untuk benar-benar melaksanakan IMD berdasarkan urutan langkah yang tepat. Hal ini juga bisa dipengaruhi faktor lain seperti jumlah ibu bersalin yang datang karena Puskesmas Gondangwetan, Winongan dan Purwodadi merupakan Puskesmas rawat Inap di Kabupaten Pasuruan dengan Pelayanan Obstetri Neonatal dan Emergensi Dasar (PONED) yang menerima rujukan dari polindes atau Bidan Praktik Mandiri sehingga perkiraan jumlah ibu yang bersalin ke Puskesmas setiap bulan tidak akan sama.

Penghargaan atau imbalan menjadi salah satu faktor yang paling kecil pengaruhnya terhadap pelaksanaan IMD di puskesmas rawat inap Kabupaten Pasuruan. Imbalan dalam hal ini bisa dalam bentuk gaji, insentif, tunjangan, ataupun kesempatan melanjutkan pendidikan. Berdasarkan hasil penelitian sebagian besar bidan memiliki imbalan dan motivasi yang kurang, namun dari hasil observasi mengenai pelaksanaan IMD didapatkan hampir seluruh bidan memiliki skor yang baik (90-100). Hal ini bidan disebabkan oleh rasa dedikasi yang bidan miliki sehingga meskipun bidan memiliki motivasi dan imbalan yang kurang, namun bidan tetap bekerja berdasarkan tanggung jawab profesional dan kompetensi yang dimiliki. Salah satu kompetensi bidan menjelaskan mengenai pemberian asuhan yang bermutu tinggi dan memimpin persalinan yang bersih, aman dan optimal (6). Inisiasi menyusu dini merupakan bagian dari asuhan persalinan yang harus diberikan bidan. Dedikasi yang

\section{DAFTAR PUSTAKA}

1. Alive and Thrive. Impact of Early Initiation of Exclusive Breastfeeding on Newborn Deaths. (Online) 2010. http://www.healthynewbornnetwork.org/sites/defa ult/files/resources/Brief\%201\%20January\%202010\%20Insight-Impact\%20of\%20early\%20initiation.pdf [accessed on 2 February 2013] dimiliki bidan dapat menurun jika pimpinan dalam hal ini kepala Puskesmas tidak memperhatikan kesejahteraan bidan. Pemberian imbalan baik secara materi maupun non-materi hendaknya perlu dijadikan pertimbangan.

Pelaksanaan IMD tidak saja dipengaruhi oleh faktor intrinsik dan ekstrinsik bidan namun kemungkinan besar juga dipengaruhi oleh faktor lain yang tidak terkaji dalam penelitian ini. Terdapat $92 \%$ pelaksanaan IMD dipengaruhi oleh faktor lain yang tidak dapat dijelaskan dalam penelitian. Besarnya pengaruh faktor lain ini menunjukkan bahwa pelaksanaan IMD tidak bisa diselesaikan hanya dengan faktor dari bidan namun juga dipengaruhi faktor lain. Faktor lain yang mungkin mempengaruhi pelaksanaan IMD adalah kebudayaan, geografis, dukungan suami, pemerintah sebagai penentu kebijakan dan faktor ibu yang meliputi pengetahuan ibu, umur gestasi bayi dan lainnya. Petugas kesehatan, dukungan suami dan keluarga berperan penting dalam pelaksanaan IMD. Tiga faktor yang terkait dengan inisiasi menyusui dalam satu jam pertama kehidupan: ibu yang menerima bimbingan prenatal mengenai keuntungan dari menyusui, persalinan pervaginam, dan kehamilan aterm (38). Penelitian mengenai IMD mendukung teori diatas bahwa kajian budaya, tradisional dan ilmiah mendukung pelaksanaan IMD segera setelah melahirkan, namun hal ini tidak dilakukan diantara tenaga kesehatan professional dan sebagian besar Rumah Bersalin. Hanya 24\% dari ibu yang bayinya diberikan dalam waktu 8 jam setelah melahirkan. Alasan yang diberikan oleh para ibu seperti rasa nyeri, kelelahan, belum keluarnya ASI dan lain-lain. Hal ini seharusnya dapat diatasi dengan konseling laktasi selama periode antenatal dan awal kelahiran bayi. Selain itu ibu yang menyusui bayinya lebih bergantung pada tradisi dan saran dari suami dan para tetua (7).

Hasil penelitian menyimpulkan bahwa pelaksanaan IMD di Puskesmas Rawat Inap Kabupaten Pasuruan di dipengaruhi langsung oleh faktor intrinsik yaitu sikap dan motivasi bidan, faktor intrinsik yang mempengaruhi adalah beban kerja. Faktor yang berpengaruh tidak langsung mempengaruhi pelaksanaan IMD adalah faktor intrinsik bidan yaitu umur, pendidikan, masa kerja \& pengetahuan serta faktor ekstrinsik yaitu pelatihan dan imbalan.

Dari hasil penelitian ini diharapkan dilakukannya penelitian sejenis di daerah lain untuk mengetahui hal-hal yang mempengaruhi hasil penelitian misalnya sosial budaya, geografi wilayah. Penelitian digunakan untuk mengembangkan upaya penyelesaian masalah yang lebih komprehensif mengenai IMD. Pemerintah dapat melakukan sosialisai tentang pelaksanaan IMD sehingga tenaga kesehatan yang berada di fasilitas kesehatan, dalam hal ini adalah bidan pelaksana dapat mengetahui informasi tersebut dan menjadikannya sebagai salah satu tanggung jawab profesi.

2. Fikawati $\mathrm{S}$ and Syafiq A. Kajian Implementasi dan Kebijakan Air Susu Ibu Eksklusif dan Inisiasi Menyusui Dini di Indonesia. Makara Kesehatan. 2010; 14(1): 1724.

3. Roesli U. Inisiasi Menyusu Dini Plus ASI Eksklusif. Jakarta: Pustaka Bunda; 2008.

4. Bupati Malang. Peraturan Bupati (Perbub) Nomor 6 
Tahun 2010 tentang Pedoman Umum Penyelenggaraan Kesehatan Ibu, Bayi Baru Lahir dan Anak (KIBBLA). Malang: Republik Indonesia; 2010.

5. Bupati Bandung. Peraturan Daerah (Perda) No: 2 Tahun 2009 tentang Kesehatan Ibu, Bayi Baru Lahir dan Anak (KIBBLA). Bandung: Republik Indonesia; 2009.

6. Kementerian Kesehatan Republik Indonesia. Profil Kesehatan Indonesia Tahun 2011. Jakarta: Kementerian Kesehatan Republik Indonesia; 2012.

7. Priscilla V. Early Breastfeeding Practice in West Sumatra, Indonesia: Determinants and Interventions for Promotion. 44th International Course in Health Development (ICHD), Amsterdam, September 24, 2007 - September 12, 2008. Amsterdam: KIT (Royal Tropical Institute) Development Policy \& Practice/Vrije Universiteit Amsterdam; 2008; p. 1-40.

8. Mangkuprawira S dan Vitayala A. Manajemen Mutu Sumber Daya Manusia. Jakarta: Ghalia Indonesia; 2007.

9. Siregar A. Pemberian ASI Eksklusif dan Faktor-faktor yang mempengaruhinya. [Tesis]. Universitas Sumatra Utara, Medan. 2004.

10. Musta'in. Pengaruh Kebijakan Institusi dan Pengetahuan Penolong Persalinan terhadap Pelaksanaan Inisiasi Menyusu Dini (IMD) di Puskesmas Klaten Utara \& RSUD Kota Surakarta. Profesi. 2012; 8: 1-7.

11. Aprillia Y. Analisis Sosialisasi Program Inisiasi Menyusu Dini dan ASI Eksklusif kepada Bidan di Kabupaten Klaten. [Tesis]. Universitas Diponegoro, Semarang. 2009.

12. Notoatmodjo S. Metodologi Penelitian Kesehatan. Jakarta: Rineka Cipta; 2010

13. Departemen Kesehatan Republik Indonesia. Pedoman Kerja Puskesmas. Jilid I. Jakarta: Direktorat Jenderal Pembinaan Kesehatan Masyarakat, Dep Kes RI; 2010.

14. Gatot DB dan Adisasmito W. Hubungan Karakteristik Perawat, Isi Pekerjaan dan Lingkungan Pekerjaan terhadap Kepuasan Kerja Perawat di Instalasi Rawat Inap RSUD Gunung Jati Cirebon. Makara Kesehatan. 2005; 9(1): 1-8.

15. Huang, TT and Wu SC. Evaluation of a Training Programme on Knowledge and Compliance of Nurse Assistants's Hand Hygiene in Nursing Homes. Journal of Hospital Infection. 2008; 68(2): 164-170.

16. Dennis C. Breastfeeding Peer Support: Maternal and Volunteer Perceptions from a Randomised Controlled Trial. Birth. 2002; 39(3): 169-176.

17. Foster DA, McLachlan HL, and Lumley J. Factor Associated with Breastfeeding at Six Months Postpartum in A Group of Australian Women. International Breastfeeding Journal. 2006; 1(18): 1 $-12$
18. Papalia DE, Old SW, and Feldman RD. Human Development. 9th ed. Canada: McGraw-Hill Co.; 2008.

19. Agunbiade OM and Ogunleye OV. Constraints to Exclusive Breastfeeding Practice among Breastfeeding Mothers in Southwest Nigeria: Implications for Scaling Up. International Breastfeeding Journal. 2012; 2(7): 110.

20. Abdul A AJ, Al-Hadi AH, and Abdulla MM. Knowledge, Attitudes and Practices of Iraqi Mothers and Family Child-Caring Women Regarding Breastfeeding. Eastern Mediterranean Health Journal. 2008; 14(5): 1003-1014.

21. Azwar S. Sikap Manusia, Teori dan Pengukurannya. Edisi ke 2. Yogyakarta: Pustaka Pelajar; 2005.

22. Spear, Hila J. Nurses' Attitudes, Knowledge, and Beliefs Related to the Promotion of Breastfeeding among Women Who Bear Children during Adolescence. Journal of Pediatric Nursing. 2004; 19(3): 176-183.

23. Patton CB, Beaman M, Csar N, and Lewinski C. Nurses' Attitudes and Behaviors that Promote Breastfeeding. Journal of Human Lactation. 1996; 12(2): 111-115.

24. Dessler G. Manajemen Sumber Daya Manusia. Jakarta: Prenhalindo; 2009.

25. Daniels L and Jackson D. Knowledge, Attitude and Practices of Nursing Staff Regarding the Baby-Friendly Hospital Initiative in Npn-accredited Obstetric Unit I Cape Town. S Afr J Clin Nutr. 2011; 24(1): 32-38.

26. Arfida. Ekonomi Sumber Daya Manusia. Jakarta: Ghalia Indonesia; 2003.

27. Levin S, France DJ, Hemphill R, et al. Tracking Workload in the Emergency Department. Human Factors. 2004; 48(3): 526-539.

28. Nitisemito, Alex S. Manajemen Personalia, Edisi Kedua. Jakarta: Ghalia Indonesia. 2006

29. Reddin E, Pincombe J, and Darbyshire P. Passive Resistance: Early Experiences of Midwifery students/graduates and The Baby Friendly Health Initiative 10 Steps of Succesfull Breastfeeding. Women and Birth. 2007; 20(2): 71-76.

30. Hidayat AAA. Pengantar Konsep Dasar Keperawatan. Jakarta: Salemba Medika; 2011.

31. Sukini T. Hubungan Pendidikan Kesehatan oleh Bidan terhadap Keberhasilan ASI Eksklusif di Kabupaten Purworejo. [Tesis]. Universitas Gajah Mada, Yogyakarta. 2006.

32. Maslow AH. Motivation and Personality. Di dalam: Nurul Iman (E3si Kerja Penyuluh Perindustrian pada Kantor Dinas Perindustrian dan Perdagangan Kota Medan. [Tesis]. Universitas Diponegoro, Semarang. 2009.

36. Hasibuan MSP. Manajemen Sumber Daya Manusia. Jakarta: Bumi Aksara; 2005.

37. SchanlerR J, O'Connor KG, and Lawrence RA. 
Pediatrician's Practices and Attitudes Regarding Breastfeeding Promotion. Pediatrics. 1999; 103 (3): E35.

38. Vieira TO, Vieira GO, Giugliani ERJ, Mendes CMC,
Martins CC, and Silva LR. Determinants of Breastfeeding Initiation within The First Hour of Life in Brazillian Population. BioMed Central Public Health. 2010; 10(760): 1-6 